Democracy

in Britain 


\section{Books in the Politics Study Guides series}

British Government and Politics: A Comparative Guide

Duncan Watts

International Politics: An Introductory Guide

Alasdair Blair, Steven Curtis and Sean McGough

US Government and Politics: An Introductory Guide

Will Storey

Britain and the European Union

Alistair Jones

The Changing Constitution

Kevin Harrison and Tony Boyd

Democracy in Britain

Matt Cole

Devolution in the United Kingdom

Russell Deacon and Alan Sandry

Elections and Voting in $U K$

Chris Robinson

The Fudiciary, Civil Liberties and Human Rights

Steven Foster

Political Communication

Steven Foster

Political Parties in Britain

Matt Cole

The Politics of Northern Ireland

Joanne McEvoy

Pressure Groups

Duncan Watts

The Prime Minister and Cabinet

Stephen Buckley

The UK Parliament

Moyra Grant 


\title{
Democracy in Britain
}

\author{
Matt Cole
}

Edinburgh University Press 
To Sue and Jessie

(C) Matt Cole, 2006

Edinburgh University Press Ltd

22 George Square, Edinburgh

Typeset in 11/13pt Monotype Baskerville by

Servis Filmsetting Ltd, Manchester, and

printed and bound in Great Britain by

Antony Rowe Ltd, Chippenham, Wilts

A CIP record for this book is available from the British Library

ISBN-10 0748623124 (paperback)

ISBN-139780748623129 (paperback)

The right of Matt Cole to be identified as author of this work has been asserted in accordance with the Copyright, Designs and Patents Act 1988.

Published with the support of the Edinburgh University Scholarly Publishing Initiatives Fund. 